\title{
Analiza korištenja preventivne aktivnosti kao odgovora na nadolazeću krizu u javnom sektoru
}

Stručni rad, DOI 10.22522/cmr20210166, primljeno 16. svibnja 2021.

UDK : 316.77:005.334

\section{Ivana Jeleč (kontakt osoba)}

Visoko učilište Algebra, Zagreb, Hrvatska.

E-adresa: ivana.jelec@racunarstvo.hr

\section{Renata Potočnik}

Millenium promocija, Zagreb, Hrvatska.

E-adresa: renata.potocnik@mpr.hr

\section{Maja Samardžić}

Millenium promocija, Zagreb, Hrvatska.

E-adresa: maja.samardzic@mpr.hr

\section{Sažetak}

Krizno komuniciranje jedno je od najizazovnijih i najsloženijih područja praktične primjene odnosa s javnošću. Javni sektor se, zbog tromosti sustava, vrlo često spominje i u kontekstu neučinkovite komunikacije, a to uključuje i reaktivan pristup kriznoj komunikaciji. U suprotnosti s ponuđenim stereotipom, ovaj rad proučava studiju slučaja krizne komunikacije u kojemu je čelnik javne institucije primijenio strategiju preventivnog protuodgovora i svojim proaktivnim istupom uzrokovao kriznu situaciju u javnoj instituciji koju je vodio te negativan publicitet. S ciljem ispitivanja ispravnosti ovog pristupa, ujedno i prvog takvog slučaja u komunikaciji hrvatskih javnih institucija, analizirane su naslovnice triju najčitanijih dnevnih listova u Hrvatskoj - 24sata, Večernjeg lista i Jutarnjeg lista - njihova online izdanja te još deset najčitanijih news portala u razdoblju od 24. rujna do 18. listopada, odnosno od sazivanja izvanredne konferencije za medije i početka krize do razrješenja Dubravka Ponoša s funkcije direktora Fonda za zaštitu okoliša i energetsku učinkovitost.

Ključne riječi: krizno komuniciranje, preventivni protuodgovor, Fond za zaštitu okoliša i energetsku učinkovitost 


\section{Uvod}

Sastavni dio poslovanja organizacija čini i kvalitetno upravljanje komunikacijskim procesima, s posebnim naglaskom na pažljivo i detaljno planiranje i vođenje komunikacije u vremenima kriza. Kada nastupi krizna situacija organizacije su i najranjivije te, iako svjesne da su krize neizostavan dio poslovnih procesa i da će se svaka organizacija s krizomsuočiti prije ili poslije, u praksi uočavamo da brojne organizacije i dalje ne razumiju kako se s njima nositi ili se s njima ne nose na ispravan i kvalitetan način. Kathleen Fearn-Banks (2002 prema Broom, 2010, str. 313) ističe kako „uspješna krizna komunikacija ovisi o predviđanju krize i temeljitom planiranju, kao i o otvorenoj i poštenoj politici prema nositeljima interesa i medijima“. Na odabir adekvatne strategije i na upravljanje svakom takvom situacijom uvelike utječe i područje u okviru kojeg se krizna situacija pojavila, ali i sama vrsta krize. Glen M. Broom (2010, str. 313), koristeći vrijeme kao presudnu varijablu u definiranju, krizne situacije dijeli na trenutačne krize, krize u nastajanju i trajne krize. Područje javnih institucija posebno je zanimljivo u kontekstu kriznog komuniciranja jer se „potpuni ili djelomični korisnici sredstava državnog proračuna“ nalaze u najgorem položaju (Tomić, 2016, str. 838). Stoga potreba za planskim scenarijem $\mathrm{u}$ javnom sektoru postaje još izraženija.

Imajući u vidu teorijsku postavku kako „koncept preventivnog protuodgovora počiva na premisi kako onaj tko prvi ispriča svoju stranu priče uvelike određuje primarni ton priče“ (Jugo, 2015, str. 185), ovaj rad analizira slučaj kriznog komuniciranja iz rujna 2019. u Fondu za zaštitu okoliša i energetsku učinkovitost u okviru kojeg je tadašnji direktor Fonda Dubravko Ponoš na konferenciji za medije objavio snimku prijetnji i uvreda koje on sam izgovara, a koja „je predmet ucjena njegovog kolege“ (Jutarnji list, 2019), kako bi javno prezentirao sve sporne informacije u konkretnom slučaju i pozadinu njihova nastajanja prije nego što to učini druga strana. Slijedom navedenoga, u radu se postavljaju pitanja je li primjena upotrijebljene strategije bila ispravan odabir te $u$ kojoj je mjeri njezina implementacija utjecala na rukovodeći kadar i na samu organizaciju. 


\section{Obilježja komunikacije javnog sektora}

Vlatka Šelimber (2019, str. 2) izjednačava komunikaciju državnih tijela s odnosima s javnošću javne uprave, pri čemu potvrđuje Broomovu tezu kako su državni službenici za odnose s javnošću, a samim time i službenici za odnose s javnošću u javnoj upravi, „presudna spona između naroda i države“ (Broom, 2010, str. 405). Njihov je primarni cilj provođenje informativnih aktivnosti o vlastitom djelovanju, zato su i prepoznati kao „zagovaratelji, odnosno odvjetnici glasa građana prema donositeljima odluka te jednako tako komunikatori usvojenih odluka prema građanima“ (Šelimber, 2019, str. 3). Kako ističu Ralph Tench i Liz Yeomans (2009, str. 640), „ministarstva, lokalna samouprava, bolnice i ostale organizacije“ - sva tijela javne uprave - „pravno su i moralno obavezna obavještavati stanovništvo i medije o odlukama u vezi s politikama i pitanjima koja imaju utjecaja na sve članove društva“"(Tench i Yeomans, 2009. str. 640).

Izvješće o provedenom istraživanju s preporukama za poboljšanje usluga koje pruža javna uprava, a koje je izdalo Ministarstvo uprave, navodi „u Hrvatskoj djeluje više od 5000 tijela javne uprave (tijela državne uprave, jedinice lokalne samouprave te pravne osobe s javnim ovlastima) koja ne čine jedinstvenu skupinu i s kojima građani nemaju jednoznačnu interakciju ili komunikaciju“ (Izvješće ${ }^{1}$, 2017). Osim što se broj tijela javne uprave u javnosti često spominje u kontekstu tromosti sustava te potrebe da se njihov broj smanji, u negativnom kontekstu spominju se i odnosi s javnošću u ovom sektoru. Kako ističe Šelimber (2019, str. 4-5), odnosi s javnošću $\mathrm{u}$ javnoj upravi u Hrvatskoj spominju se u kontekstu spina i manipulativne komunikacije, a zapravo je njihova zadaća stvaranje dvosmjernog odnosa i ostvarivanje transparentne, pravodobne i kvalitetne komunikacije koja se postiže strateškim planiranjem te proaktivnim i prikladnim reakcijama. S obzirom na složenost komunikacijskih procesa $u$ javnoj upravi i utjecaj aktivnosti svakog tijela na živote građana, „neophodno je da u tom području rade obrazovani i osposobljeni stručnjaci koji znaju kako uspostaviti kvalitetne odnose s javnostima i održati ih, razumljivo prenositi informacije, ispravno reagirati na krizne situacije te istodobno služiti kao korektiv onima koji upravljaju institucijom“ (Šelimber, 2019, str. 5).

Pokazujući spremnost na komunikaciju i ostvarivanje dvosmjernih odnosa koji počivaju na osluškivanju i pravovremenim reakcijama te pružanju odgovora na tražena pitanja, tijela javne uprave pokazuju odgovornost prema javnosti. Osim kampanja kojima organizacije,

1 Izvješće o provedenom istraživanju s preporukama za poboljšanje usluga koje pruža javna uprava izdalo je Ministarstvo uprave na temelju provedenog istraživanja o zadovoljstvu građana uslugama koje pruža javna uprava (Izvješće, 2017: 3). 
odnosno tijela javne uprave obavještavaju javnost o svojim aktivnostima (Tench, Yeomans, 2009, str. 641), ključnu ulogu u kontekstu odgovornosti u javnom sektoru imaju mediji (Tench, Yeomans, 2009, str. 640). Neovisno o tome je li riječ o javnom ili privatnom sektoru, medije se može doživljavati kao saveznike, neutralne promatrače događanja ili kao neprijatelje. Danas, za razliku od prijašnjih vremena u kojima je medijima dominirala mala skupina moćnih novinara i urednika, društvo ima na raspolaganju brojne medije koji su sveprisutni i imaju mogućnost baviti se određenim temama (Tkalac Verčič, 2015, str. 369) te tako svojoj publici nuditi specijalizirani sadržaj. Stoga, kako navode Dejan Verčič i sur. (2004, str. 81), „imalo ozbiljna organizacija neće svoje odnose s medijima prepustiti stihiji i slučajnostima“, a ista se tvrdnja može primijeniti i na odnose s medijima u javnom sektoru. Nažalost, kako navodi Zoran Tomić (2016, str. 836), „državna administracija, odnosno javne institucije okarakterizirane su sporim otvaranjem prema medijima i neučinkovitošću“, što u konačnici utječe i na brzinu rješavanja krizne situacije. U uspostavljanju odnosa s medijima ključno je imati osobu za odnose s javnošću koja će biti upućena u medijsku scenu te biti kompetentna raspoznati koji novinari prate određeno područje, odnosno znati kojim se medijima i novinarima obratiti u plasiranju određene teme. U razvoju odnosa s medijima potrebno je biti im na raspolaganju, uspostaviti korektan odnos pun povjerenja i održavati ga. „Suradnja i razumijevanje, kao i pozitivan stav, dobra su osnova za izgradnju kvalitetnih odnosa s medijima, na što se nadovezuju dostupnost i brzina, dvije značajke koje su u istraživanju o odnosima s medijima $u$ lokalnoj i regionalnoj samoupravi u Hrvatskoj novinari naveli kao najvažnije u komunikaciji s osobama koje se bave odnosima s medijima“"(Šelimber, Jalušić, 2019, str. 22).

\section{Specifičnosti krizne komunikacije javnog sektora}

Krizno komuniciranje čini sastavni dio strateškog komunikacijskog plana i strategije svake organizacije jer se s ovom, izrazito izazovnom vrstom komuniciranja, svi susreću prije ili kasnije, neovisno o tome na kojoj vrsti tržišta posluju ili kojim dionicima se obraćaju - pa tako i javni sektor. Samo krizno komuniciranje okarakterizirano je kao „znanstvena disciplina koja je rezultat svih kriznih poruka i komunikoloških zakonitosti, posebno onih koje se bave ponašanjem pojedinca i organizacije u kriznim situacijama. Strateški usmjerena i upravljana komunikacija, a posebno u kriznim situacijama, značajno pomaže korporacijama u ostvarivanju 
uspješne ili neuspješne komunikacije u svom okruženju“ (Plenković, 2015, str. 113). Kriza je, u svakom slučaju, nezaobilazni dio rada i razvoja svake organizacije, dok je krizna situacija definirana kao neželjeni i neplanirani proces koji traje jedno određeno vrijeme i na koji je moguće samo djelomično utjecati. Kako ističe Tomić (2016, str. 838), govoreći o komunikaciji javnih institucija, odnosno institucija korisnika državnog proračuna, veličina organizacije proporcionalna je složenošću suočavanja s kriznim situacijama. Javni sektor posebno je podložan kriznim situacijama uzme li se u obzir nedovoljna suradnja s predstavnicima medija i složenost komunikacije te odgovornost koju javni sektor ima prema građanima.

Uz rastuću pozitivnu percepciju odnosa s javnošću, sve veću važnost održavanja odnosa sa svim dionicima te otvorenu komunikaciju na različitim razinama, i krizna komunikacija organizacija dobivala je sve značajniju stratešku ulogu. Herman Kahn i Anthony J. Wiener (2000 prema Osmanagić Bedenik, 2010, str. 104) navode da „kriza predstavlja točku preokreta u razvojnom slijedu događaja i aktivnosti, stvara situaciju u kojoj je visoka hitnost djelovanja, proizlazi iz slijeda događaja koji rezultira novim uvjetima, povećava hitnost, stres i strah, povećava vremenski pritisak, mijenja odnose između članova te povećava napetost“. Damir Jugo (2017, str. 12) ističe da je „kriza sve ono što može prouzročiti iznenadnu i ozbiljnu štetu zaposlenima, njezinu ugledu ili financijskom rezultatu, ali da jednako tako krize mogu biti i kotač zamašnjak konstruktivnih promjena, rasta i obnove“. Kako ističu Christine M. Pearson i Judith A. Clair (1998 prema Broom, 2010, str. 317), „učinkovito krizno upravljanje podrazumijeva improviziranje i uzajamno djelovanje ključnih nositelja interesa kako bi se nanovo izgradila individualna i kolektivna svijest, zajedničko poimanje problema i uloge. Nakon događaja koji pokreće krizu, učinkovito krizno upravljanje povlači za sobom individualnu i organizacijsku ponovnu prilagodbu temeljnih pretpostavki, kao i reakcije na razini ponašanja i emocija koje podupiru oporavak i ponovnu prilagodbu.“

Neovisno o kojem je sektoru riječ - privatnom ili javnom - „kriza se uvijek pojavljuje s određenim značajkama i elementima. Pojavljuje se naglo, često bez ikakvih prethodnih najava. Traži brzu reakciju, otežava funkcioniranje organizacije i uzrokuje nesigurnost i stres. Kriza ugrožava reputaciju organizacije i ostale njezine vrijednosti, eskalira u intenzitetu te uzrokuje pomno ispitivanje i trajno mijenjanje organizacije od strane vanjskih čimbenika.“ (Tomić, 2016, str. 206)

Kada se dogodi, kriza jednako pogađa svaku vrstu organizacije i iz nje uspijevaju uspješno izaći samo one organizacije koje su bile usmjerene na ispravno i strateško upravljanje 
komunikacijom u svim fazama kriznog razdoblja. Fearn-Banks (1993 prema Jugo, 2017, str. 91) pritom krizno upravljanje opisuje kroz pet faza kao što su: (1) prepoznavanje; (2) priprema, odnosno prevencija; (3) ograničavanje; (4) oporavak i (5) učenje. Tijekom navedenih faza organizacija prati znakove upozorenja, bilježi ih i priprema proaktivne ili reaktivne planove za suočavanje s kriznom situacijom, poduzima korake za ograničavanje krizne situacije i učinaka, provodi korake za povratak u stabilno stanje te provodi proces evaluacije (Fearn-Banks, 1993 prema Jugo, 2017, str. 91). Evaluacija krizne komunikacije u javnom sektoru pomaže organizaciji, tijelu javne uprave, utvrditi je li bilo moguće izbjeći kriznu situaciju te na koji način je moguće unaprijediti akcijski plan djelovanja.

Suvremeno društvo se konstantno mijenja, zbog čega je za organizaciju nužno pratiti okolinu i sve procese koji se u njoj događaju kako bi organizacija mogla moći predvidjeti događaje te na vrijeme početi planirati komunikaciju. „Planirana, strateška komunikacija kontinuirano dobiva na važnosti, jer se suvremeno društvo sve više okreće prema budućnosti koju možemo samo zamišljati i o kojoj možemo samo raspravljati“ (Verčič, 2016). Stoga, što prije vodeći kadar organizacije otkrije naznake potencijalnih događaja, prije će moći donijeti učinkovite odluke i utjecati na smjer njihova rješavanja. Zbog kontinuiranih pojava kriza, redovito se objavljuju i nove definicije krize, iako sve one $u$ konačnici imaju tri zajednička faktora kao što su: (1) veličina - jer kriza nikad nije manji incident već događaj ili niz događaja većih razmjera; (2) šteta koja se odnosi na sve moguće štetne posljedice za organizaciju, ljude i reputaciju te (3) neočekivanost, s obzirom da je veličina krize nešto što se moglo očekivati, međutim menadžment iz različitih razloga ignorira znakove upozorenja (Tafra-Vlahović, 2013, str. 14).

\section{Strateški pristup kriznoj komunikaciji}

Strateški pristup kriznoj situaciji odgovor je organizacije na krizu te je rezultat strateškog promišljanja, analiza i donošenja odluka. Fearn-Banks (2001 prema Jugo, 2017, str. 2) krizno upravljanje opisuje kao „proces strateškog planiranja kojem je ključna svrha reagirati tijekom krizne situacije ili u negativnim okolnostima, odnosno u procesu koji uklanja dio rizika i nesigurnosti te dopušta organizaciji da učinkovitije upravlja svojom sudbinom“. Kako navodi Ronald Smith (2009 prema Jugo, 2017, str. 34), „strateško komuniciranje se događa u konkretnom okružju koje podrazumijeva i organizaciju i skupine ljudi na koje na određeni

način utječe te se može usporediti s komunikacijskim kampanjama kojima je glavna svrha 
transformacija komunikacijskih prepreka u prilike za organizaciju i njezine dionike“. Postoje primjeri organizacija u kojima se pokazuje razumijevanje teorijskih pravila i strategija postupanja u kriznim situacijama, ali oni potom u praksi pokazuju svoje manjkavosti jer svaka krizna situacija zahtijeva potpuno individualan i specifičan pristup te promišljanje kako $u$ konačnici ne bi bila nanesena šteta organizaciji i bilo dovedeno u pitanje poslovanje i upravljanje organizacijom, jednako kao i njezin ugled i reputacija.

Komuniciranje u svakoj krizi je neizbježno, ali pristup i odabir strategije značajno ovise o njezinoj složenosti. Tako postoje krize koje traže trenutačnu reakciju prema različitim javnostima, dok u određenim vrstama kriza treba pričekati s istupanjem u javnost jer bi trenutačna reakcija mogla izazvati još veću krizu. „Važno je da komunikacija ide u smjeru koji vodi razrješavanju krize te uspostavljanju normalnih i kvalitetnih odnosa s dionicima“ (Prokić i sur., 2011, str. 157-159). Situacijska krizna teorija komunikacije (engl. situational crisis communication theory, SCCT) usredotočuje se na uporabu strategija radi očuvanja ugleda organizacije, a razvila se iz konvergencijskih crta komunikacijskog istraživanja čiji je zaključak da učinkovitost komunikacijskih strategija ovisi o karakteristikama krizne situacije, uz argument da situacija pomaže odrediti prikladan odgovor (Milas, 2011, str. 127). Reputacija organizacije ovisi o reakciji na kriznu situaciju te je važna za daljnji opstanak organizacije, a situacijska teorija komunikacije pokazuje kako je najbolji način za zaštitu reputacije izbor

strategije koja će najbolje odgovarati prijetnji. Pritom se „prijetnjom smatra proces koji se sastoji od faze prepoznavanja krize i faze određivanja povijesti kriznih situacija u organizaciji“ (Heath i sur., 2006, str. 203). U trenutku kada se prijetnja već pojavila, važno je poduzeti ključne korake koji će umanjiti potencijalnu štetu i utjecati na vraćanje povjerenja i održavanje reputacije organizacije u javnosti. Reputacija se pritom zasniva na svim dojmovima javnosti, ali se stvara i na temelju izravnog ili neizravnog osobnog iskustva te oslikava ukupnu atraktivnost poduzeća prema svim važnim dionicima (Milas, 2011, str. 70-72).

\subsection{Reaktivni pristupi Ronalda Smitha}

Nastanak krize organizaciju stavlja u poziciju u kojoj mora pristupiti odabiru i primjeni određene reaktivne strategije, a što je ujedno i „ključni element kriznog komunikacijskog djelovanja“ (Jugo, 2017, str. 201). Jugo također navodi da je Ronald Smith pružio jednu od najkvalitetnijih tipologija reaktivne strategije (Jugo, 2017, str. 203). Smithova tipologija ističe tri pristupa 
relevantna za komunikacijski odgovor na negativne situacije. Prvi pristup je temeljen na apologiji, odnosno službenoj obrani koja „objašnjava snažne okolnosti vezane uz mišljenja, poziciju ili aktivnosti organizacije u negativnoj situaciji, čime organizacija objašnjava svoje aktivnosti i poziciju, uvjeravajući kritičare u njihovu ispravnost“"(Jugo, 2012, str. 186). Potom slijedi teorija obračuna koja se odnosi na „upotrebu komunikacije u upravljanju odnosima u slučaju predbacivanja ili snažne kritike“ (Jugo, 2012, str. 186), dok je treća teorija obnove imidža koja, u što kraćem vremenu, traži način da vrati pozitivan imidž (Jugo, 2012, str. 186).

Referirajući se na strategije kojima pojedina organizacija može odgovoriti na krizu, Smith (2012 prema Jugo, 2017, str. 203) razlikuje sedam skupina reaktivnih strategija, među kojima su: preventivne aktivnosti, napadački odgovor, obrambeni odgovor, zavaravajući odgovor, javno sažaljenje, korektivno ponašanje i strateška neaktivnost, a koje objedinjuju 25 strategija (Jugo, 2017: 203). Rad je usmjeren na preventivne aktivnosti (eng. pre-emptive action), odnosno strategiju preventivnog odgovora (eng. prebuttal) u okviru koje organizacija samostalno objavljuje negativne informacije o vlastitom djelovanju prije negoli to učine oponenti (Smith, 2016). Kako navodi Smith (2016), pojedini birokrati izbjegavaju ovu strategiju u nadi da po njih negativne informacije neće nikada ni biti otkrivene, zanemarujući komunikacijsku smjernicu da onaj tko prvi iznese priču njome kasnije i upravlja.

\section{Korištenje preventivne aktivnosti kao odgovora na nadolazeću krizu u javnom sektoru}

Krizna situacija predstavlja komunikacijski izazov i najiskusnijoj organizaciji, a kako bi se ona što učinkovitije i po pogođenu stranu što brže riješila, potrebno je slijediti četiri osnovna pravila krizne komunikacije: djelovati brzo, voditi računa o ljudskim žrtvama i dobrobit ljudi postaviti na prvo mjesto, doći na mjesto događaja te otvoreno komunicirati (Luecke, 2005, str. 42).

U trenucima kad je očito da će javnost čuti optužbe ili loše vijesti o organizaciji, komunikacijska smjernica svakog iskusnog komunikacijskog stručnjaka jest da čelna osoba organizacije upotrijebi preventivni protuodgovor, jer „ako organizaciju ili pojedinca netko drugi preduhitri u objavi onoga što se dogodilo ili pošlo krivo, njihova službena verzija zasigurno neće biti najbolja za njezin ugled“ (Jugo, 2017, str. 204). Kako navodi Jugo (2017, str. 204), 
„korištenje ovom strategijom daleko je najučinkovitije onog trenutka kad su organizacija i njezin komunikacijski tim potpuno sigurni da će javnost iz nekoga nekontroliranog izvora čuti optužbe na njihov račun ili informacije koje joj mogu štetiti, ali i kada organizacija može javnosti ponuditi snažne i čvrste dokaze da zanemare loše vijesti i opravdaju organizaciju“.

Premda se njezina primjena čini neizbježna i apsolutno neophodna u svakoj kriznoj situaciji, ako postoji mogućnost da se iznošenjem negativnih informacija u javnosti stvori više publiciteta i zainteresira publika više no što bi se to dogodilo ne iznošenjem informacija, preporučuje se ne koristiti ovu strategiju. Ključ primjene svake, pa tako i ove strategije, nalazi se u adekvatnoj analizi situacije i nastojanja da se što učinkovitije umanji negativan utjecaj kritičara na pojedinca ili organizaciju.

\subsection{Studija slučaja Fonda za zaštitu okoliša i energetsku učinkovitost}

U suvremenom vremenu u kojem živimo, u kojem se informacije razmjenjuju na različitim platformama strelovitim brzinom, strategija preventivnog odgovora predstavlja „uobičajeni način na koji organizacija nastoji umanjiti utjecaj mogućih kritika na vlastiti račun“ (Jugo, 2017, str. 204). Ova se strategija često koristi u političkim arenama (Smith, 2016), a što se dogodilo i u slučaju Fonda za zaštitu okoliša i energetsku učinkovitost, odnosno istupa tadašnjeg direktora Dubravka Ponoša. Ovo je ujedno i prvi slučaj u komunikaciji hrvatskih javnih institucija $u$ kojem je čelna osoba javne institucije izabrala strategiju preventivnog protuodgovora i svojim istupom organizaciji koju je vodio stvorio potrebu za kriznom komunikacijom istovremeno stvorivši instituciji negativan publicitet.

Fond za zaštitu okoliša i energetsku učinkovitost (FZOEU, u nastavku Fond) osnovan je krajem 2003. kao „izvanproračunska institucija s ciljem sufinanciranja projekata zaštite okoliša i energetske učinkovitosti. Ulaskom Hrvatske u Europsku uniju, Fond je stekao dvojaku ulogu, $s$ jedne strane kao pružatelj tehničke pomoći zainteresiranima za projekte energetske obnove privatnih i javnih zgrada, a s druge strane kao Posredničko tijelo razine 2 , evaluacijsko tijelo za navedene projekte“ (Fond za zaštitu okoliša i energetsku učinkovitost, 2017). Osnovne djelatnosti Fonda vezane su za financiranje pripreme, implementacije i razvoja programa i projekata u području očuvanja održivog „korištenja, zaštite i unapređivanja okoliša i u području energetske učinkovitosti i korištenju obnovljivih izvora energije“" (Fond za zaštitu okoliša i energetsku učinkovitost, 2020a). Tijela Fonda čine Upravni odbor i direktor čije su 
odgovornosti propisane Statutom Fonda (Fond za zaštitu okoliša i energetsku učinkovitost, 2020b), a koje imenuje Vlada Republike Hrvatske. Prema organigramu Fonda (Fond za zaštitu okoliša i energetsku učinkovitost, 2020c), direktor Fonda ima zamjenika pod čijom je nadležnošću čak 11 jedinica među kojima se nalazi šest posebnih sektora, tajništvo i četiri službe. Zanimljivo je da je Služba za odnose s javnošću izdvojena te se nalazi u razini zamjenika direktora (Fond za zaštitu okoliša i energetsku učinkovitost, 2020c) iz čega proizlazi da Fond ima linijsko-stožerni model upravljanja. Prema navedenom modelu, linijske funkcije imaju funkciju proizvodnje i generiranja profita, dok stožerne imaju ulogu savjetovanja u različitim segmentima poslovanja - od financija do odnosa s javnošću i ljudskih potencijala (Milas, 2011, str. 77).

U središte pozornosti javnosti Fond za zaštitu okoliša i energetsku učinkovitost je došao u rujnu 2019. kada je tadašnji direktor Fonda Dubravko Ponoš sazvao konferenciju za medije na kojoj je objavio audio snimku nastalu u studenom 2018. na kojoj je snimljeno kako on izgovara niz prijetnji i uvreda, potaknut ucjenama bivšeg predsjednika Radničkog vijeća Fonda za zaštitu okoliša i energetsku učinkovitost Mislava Kotarca (Direktor Fonda za okoliš pustio snimku, 2019). Na izvanrednoj konferenciji Ponoš je naveo kako „,nema nikakvog opravdanja za korištenje izraza koje je koristio, bez obzira što je razgovor tajno snimljen“ $i$ objasnio da se na javnu objavu snimke odlučio nakon pritisaka i nakon što ga je Kotarac ucijenio većim koeficijentom (Direktor Fonda za okoliš pustio snimku, 2019). Gostujući na N1 Televiziji Ponoš se obrušio na kolege „te je također govorio o odgovornosti resornog ministra“ (N1 Hrvatska, 2019c), dok je Kotarac negativno komentirao rad Fonda (N1 Hrvatska, 2019b). Ubrzo nakon objave snimke, ostavku direktora Fonda zatražio je resorni ministar zaštite okoliša i energetike Tomislav Ćorić (Hina, 2019a), predsjednik Hrvatske narodne stranke - liberalni demokrati Predrag Štromar također je rekao da očekuje da podnese ostavku te je Ponoš prvo dao mandat na raspolaganje na sve stranačke funkcije u Hrvatskoj narodnoj stranci - liberalni demokrati na raspolaganje (N1 Hrvatska, 2019a), a potom je ponovno sazvao konferenciju za medije (26. rujna 2019.) na kojoj je stavio mandat u Fondu na raspolaganje. Potom su uslijedili i izvidi policije (Hina, 2019b) i u konačnici razrješenje direktora Fonda za zaštitu okoliša i energetsku učinkovitost na sjednici Vlade Republike Hrvatske (Hina, 2019c). 


\subsubsection{Analiza medijskog izvještavanja o slučaju Dubravka Ponoša}

Istraživačko pitanje glasi: „Je li u slučaju direktora Fonda za zaštitu okoliša i energetsku učinkovitost Dubravka Ponoša koji je do 17. listopada 2019. obnašao funkciju direktora Fonda za zaštitu okoliša i energetsku učinkovitost te objavljivanja sporne snimke ucjene primjena odabrane strategije preventivnog protuodgovora bila ispravan odabir te u kojoj je mjeri njezina implementacija utjecala na rukovodeći kadar i na samu organizaciju?“

Pod pretpostavkom da je odgovor na istraživačko pitanje pozitivan, provedena je analiza medijskog izvještavanja o navedenom slučaju. U analizu medijskog izvještavanja uključena su tri najčitanija hrvatska dnevna lista dnevna lista (V. B. / Hina, 2020) - 24sata, Večernji list i Jutarnji list - njihova online izdanja te još deset najčitanijih news portala u Hrvatskoj (Gemius, 2019). Analiza se odnosi na 25 dana u razdoblju od 24. rujna do 18. listopada 2019., odnosno od dana održavanja konferencije za medije na kojoj je javno objavljena audio snimka do dana nakon što je na sjednici Vlade 17. listopada 2019. uslijedila odluka o razrješenju direktora Fonda za zaštitu okoliša i energetsku učinkovitost.

Analiza uključuje ukupno 72 naslovnice dnevnih novina te 120 online članaka. Samo je Jutarnji list objavio vijest na naslovnici tiskanog izdanja i to 25. rujna, dan nakon što je objavljena sporna audio snimka na konferenciji za medije. Najviše članaka o „slučaju Ponoš“ objavljeno je na portalu N1 Televizije - N1info.com (20), a slijedi Tportal.hr s objavljenih 18 članaka. Najmanje članaka objavljeno je na portalu tjednika Express - Express.hr - samo jedan, a uz njega dva portala s najmanjim broj objava su Poslovni.hr (3) i Net.hr (5).

Tablica 1. Prikaz ukupan broj članaka o slučaju Ponoš na najčitanijim news portalima u Hrvatskoj u periodu od 24. rujna do 17. listopada 2019.

\begin{tabular}{|l|l|}
\hline MEDIJ & BROJ ČLANAKA \\
\hline Portal N1 Televizije & 20 \\
\hline Tportal.hr & 18 \\
\hline RTL.hr & 12 \\
\hline Jutarnji.hr & 10 \\
\hline Telegram.hr & 10 \\
\hline Večernji.hr & 10 \\
\hline Dnevno.hr & 9 \\
\hline Direktno.hr & 8 \\
\hline 24sata.hr & 7 \\
\hline Dnevnik.hr & 7 \\
\hline Net.hr & 5 \\
\hline Poslovni.hr & 3 \\
\hline Express.24sata.hr & 1 \\
\hline
\end{tabular}


Teme članaka objavljenih na portalima pratile su kronologiju događaja, pri čemu su s odmakom vremena, uz spornu snimku, u fokus javnosti dodatno stavljeni odnosi u Fondu te mogućnost ranijeg saznanja za ovaj događaj u resornom ministarstvu, čime je priča održavana u javnosti i duže nego što je bilo željeno i predviđeno. Sukladno navedenom, članke je tematski moguće podijeliti u 23 teme: počevši s objavljivanjem snimke na konferenciji za medije i reakcija svih uključenih u događanje, preko reakcija resornog ministra Tomislava Ćorića, pa sve do provođenja istrage, stavljanja mandata na raspolaganje od strane Dubravka Ponoša i njegovog razrješenja s mjesta direktora Fonda za zaštitu okoliša i energetsku učinkovitost. Najviše je članaka bilo vezano uz temu stavljanja mandata na raspolaganje od strane Dubravka Ponoša, dok je najmanje bilo vezano za reakciju Socijaldemokratske partije Hrvatske na događanje te portret Mislava Kotarca, predsjednika Radničkog vijeća Fonda za zaštitu okoliša i energetsku učinkovitost koji je i snimio prijetnje direktora Dubravka Ponoša.

Tablica 2. Analiza naslova članaka prema temi o slučaju Ponoš na najčitanijim news portalima u Hrvatskoj u periodu od 24. rujna do 17. listopada 2019.

\begin{tabular}{|c|c|}
\hline TEME ČLANAKA & BROJ ČLANAKA \\
\hline Dubravko Ponoš daje mandat na raspolaganje & 21 \\
\hline Policija i DORH provode izvide & 11 \\
\hline Reakcija Mosta i optužbe prema ministru Ćoriću i Vladi RH da su bili upoznati s događanjem & 10 \\
\hline Razrješenje Dubravka Ponoša s mjesta direktora Fonda za zaštitu okoliša i energetsku učinkovitost & 9 \\
\hline Ministar zaštite okoliša i energetike Tomislav Ćorić traži ostavku direktora Fonda & 8 \\
\hline Objavljivanje snimke na konferenciji za medije & 8 \\
\hline $\begin{array}{l}\text { Potpredsjednik Vlade RH i predsjednik HNS-a Predrag Štromar traži ostavku Dubravka Ponoša na } \\
\text { mjesto direktora Fonda za zaštitu okoliša i energetsku učinkovitost }\end{array}$ & 7 \\
\hline Reakcija Mislava Kotarca & 6 \\
\hline O Fondu za zaštitu okoliša i energetsku učinkovitost & 5 \\
\hline Dubravko Ponoš objašnjava pozadinu snimke i razloge objavljivanja & 5 \\
\hline Reakcija resornog ministra Tomislava Ćorića & 5 \\
\hline Odnos Hrvatske narodne stranke - liberalni demokrati i ostalih stranaka u Vladi RH & 4 \\
\hline Reakcija Olega Butkovića (HDZ) & 4 \\
\hline Reakcija HNS-a, stranke Dubravka Ponoša & 4 \\
\hline Sazivanje nove (druge) konferencije za medije & 3 \\
\hline Moguća otpremnina i korištenje modela $6+6$ & 3 \\
\hline Portret Dubravka Ponoša & 2 \\
\hline Ministar Ćorić i HNS zajedno traže ostavku Dubravka Ponoša & 1 \\
\hline Odnosi u Vladi RH, reakcija ministra Tomislava Ćorića i ostalih političkih opcija & 1 \\
\hline Portret Mislava Kotarca & 1 \\
\hline Pozadina objavljivanja snimke & 1 \\
\hline Reakcija Mihaela Zmajlovića (SDP) & 1 \\
\hline
\end{tabular}


Teorijska pretpostavka prema kojoj „onaj tko prvi objavi svoju stranu priče uvelike određuje primarni ton“ (Jugo, 2018, str. 204) u „slučaju Ponoš“ se samo djelomično ispostavila točnom. Naime, Smith (2009 prema Jugo, 2017, str. 204) ističe kako „objava svoje verzije događaja prije svih jedna je od poželjnih i pozitivnih normi kriznoga komuniciranja s obzirom na to da će se sve druge verzije, koje će se naknadno pojaviti o organizaciji ili pojedincu, razmatrati u tom kontekstu i u daljnjoj raspravi referirati na ono što je prvo izrečeno “. Ipak, polazeći od te pretpostavke, treba uzeti u obzir ukupan broj objavljenih i analiziranih članaka čija je objava potaknuta upravo navedenom konferencijom za medije kojom je tema i otvorena $\mathrm{u}$ javnosti. Također, sama objava snimke i izrečeno pojašnjenje slučaja u konačnici nisu rezultirali željenim i očekivanim smjerom komunikacije koji je postavljen u trenutku objave sporne snimke nego su dodatno postavili temu sukoba u Fondu za zaštitu okoliša i energetsku učinkovitost na medijsku agendu. Mediji su u konačnici temu razgranali u više smjerova te su se u narednom razdoblju od gotovo mjesec dana bavili osobnošću i načinom rada i upravljanja direktora Fonda Ponoša, potom predsjednika Radničkog vijeća Kotarca, kao i odnosima u Fondu i načinom rada Fonda, da bi cijela priča bila zaključena tek razrješenjem direktora Fonda na sjednici Vlade Republike Hrvatske.

\section{Zaključak}

Krizna situacija neizostavan je dio poslovanja svake organizacije i mogućnost njezina nastanka uvijek postoji, neovisno o tome radi li se o unutarnjim ili vanjskim uzrocima njezina nastanka te o tome u kojoj mjeri je ona mogla biti djelomično ili možda u potpunosti spriječena. Slučaj Fonda za zaštitu okoliša i energetsku učinkovitost pokazuje koliko je važno pažljivo analizirati svaki segment određene situacije kako bi se izabrala najbolja komunikacijska strategija i aktivnost kao odgovor na krizu. U ovom slučaju je upravo to izostalo, što je dovelo do uzrokovanja dodatne krize organizacije, a u konačnici i razrješenja njezina čelnog čovjeka. Naime, važan segment strategije preventivnog odgovora je sigurnost da će druga strana zaista objaviti sporne informacije te, u ovom slučaju još važnije, mogućnost da organizacija osigura i javnosti prezentira iznimno snažne i čvrste dokaze zbog kojih će loša vijest biti zanemarena, a organizacija opravdana, čime će se izbjeći nanošenje dodatne štete i umanjiti utjecaj na ugled i reputaciju organizacije koja se temelji upravo na dojmovima javnosti. U slučaju Fonda za zaštitu okoliša i energetsku učinkovitost je taj važan segment izostao, zbog 
čega se dogodilo upravo suprotno te su Fond za zaštitu okoliša i energetsku učinkovitost, odnosi unutar organizacije, njezino poslovanje te način rada direktora postali teme kojima su se mediji bavili u narednom razdoblju, čime se stvorilo više publiciteta i zainteresirala publika više nego što bi to bio slučaj da informacije nisu iznesene na način na koji je to učinjeno. Iako je primjena ove strategije korištena u najboljoj namjeri, djelomično i nedovoljno razumijevanje teorijske razine krizne komunikacije te mogućnosti njezine implementacije u praksi uzrokovale su dodatnu krizu i negativan medijski publicitet koji je gotovo mjesec dana pratio organizaciju i u konačnici nanio najviše štete osobi koja je priču potaknula i otvorila u javnosti. Time se još jednom potvrdilo da je ključ primjene svake komunikacijske strategije detaljna analiza krizne situacije iz koje slijedi pravilan odabir aktivnosti i upravljanje odabranim načinom njezina rješavanja, a sve s ciljem što manjeg negativnog utjecaja na ugled i reputaciju i pojedinca i organizacije.

\section{Literatura}

- Broom, G. M. (2010). Cutlip\&Center's Učinkoviti odnosi s javnošću. MATE.

- Fearn-Banks, K. (2011). Crisis Communications: A Casebook Approach. Routledge.

- Fond za zaštitu okoliša i energetsku učinkovitost (2017). Hrvatski Fond uzor bosanskim fondovima koji se bave energetskom učinkovitošću i zaštitom okoliša. Fond za zaštitu okoliša i energetsku učinkovitost. Dostupno na: https://www.fzoeu.hr/hr/novosti/ hrvatski fond_uzor bosanskim fondovima_koji se bave_energetskom_ucinkovitoscu_i zastitom_okolisa/, 10. srpnja 2021.

- Fond za zaštitu okoliša i energetsku učinkovitost (2020a). Djelatnost Fonda. Fond za zaštitu okoliša i energetsku učinkovitost. Dostupno na: https://www.fzoeu.hr/hr/o fondu/djelatnost fonda/, 10. srpnja 2021.

- Fond za zaštitu okoliša i energetsku učinkovitost (2020b). Organizacijska struktura. Fond za zaštitu okoliša i energetsku učinkovitost. Dostupno na: https://www.fzoeu.hr/hr/o fondu/organizacijska_struktura/, 10. srpnja 2021.

- Fond za zaštitu okoliša i energetsku učinkovitost. (2020c). Organizacijska struktura. Fond za zaštitu okoliša i energetsku učinkovitost. Dostupno na: https://www.fzoeu.hr/docs/organizacijska_struktura_fzoeu_v1.pdf, 10. srpnja 2021.

- Heath, R., Coombs, T. (2006). Today's Public Relations - An Introduction. Sage Publications.

- Hina (2019a). Ministar Ćorić traži ostavku direktora Fonda za zaštitu okoliša Dubravka Ponoša. Hrvatska izvještajna novinska agencija. Dostupno na: http://hr.n1info.com/Vijesti/a446289/Ministar-Coric-trazi-ostavku-direktora-Fonda-za-zastitu-okolisaDubravka-Ponosa.html, 10. srpnja 2021.

- Hina (2019b) Policija i DORH provode izvide zbog Ponoševe audio snimke. Hrvatska izvještajna novinska agencija. Dostupno na: http:/hr.n1info.com/Vijesti/a446987/Policija-i-DORH-provode-izvide-zbog-Ponoseve-audio-snimke.html, 10. srpnja 2021.

- Hina (2019c). Vlada razriješila Dubravka Ponoša s čelnog mjesta Fonda za zaštitu okoliša. Hrvatska izvještajna novinska agencija. Dostupno na: http://hr.n1info.com/Vijesti/a452275/Vlada-razrijesila-Dubravka-Ponosa-s-celnog-mjesta-Fonda-Za-zastituokolisa.html, 10. srpnja 2021.

- Izvješće (2017). Izvješće o provedenom istraživanju s preporukama za poboljšanje usluga koje pruža javna uprava. Ministarstvo uprave. Dostupno na: https://uprava.gov.hr/UserDocsImages/Etika/2016/Izvje\%C5\%A1taj\%20o\%20provedenom\%20 istra\%C5\%BEivanju\%20zadovolistva\%20gra\%C4\%91ana\%20uslugama\%20javne\%20uprave\%20(rujan\%202016.).pdf, 10. srpnja 2021.

- Jalušić, M. (2019). Krizno komuniciranje.U: Pavlek, M. (ur.), Komunikacija od A do uprava - priručnik za komuniciranje u javnom i neprofitnom sektoru (str. 28-36). Hrvatska udruga za odnose s javnošću.

- Jugo, D. (2012). Strategije odnosa s javnošću. Profil Knjiga i Novelti Millenium.

- Jugo, D. (2017). Menadžment kriznog komuniciranja. Školska knjiga. 
- Jutarnji list (2019). DIREKTOR FONDA ZA OKOLIŠ PUSTIO SNIMKU NA KOJOJ PSUJE I PRIJETI 'Nema nikakvog opravdanja za korištenje izraza, ova snimka je predmet ucjena!'. Lutarnji.hr. Dostupno na: https://www.jutarnji.hr/vijesti/hrvatska/direktorfonda-za-okolis-pustio-snimku-na-kojoj-psuje-i-prijeti-nema-nikakvog-opravdanja-za-koristenje-izraza-ova-snimka-jepredmet-ucjena-9397517, 10. srpnja 2021.

- Luecke, R. (2005). Upravljanje kriznim situacijama. Zgombić \& Partneri.

- Milas, Z. (2011). Uvod u korporativnu komunikaciju. Novelti Millenium.

- N1 Hrvatska (2019a). Dubravko Ponoš dao mandat na raspolaganje na sve stranačke funkcije u HNS-u. N1info.com. Dostupno na: http://hr.nlinfo.com/Vijesti/a446489/Dubravko-Ponos-dao-mandat-na-raspolaganje-na-sve-stranacke-funkcije-u-HNS-u. html, 10. srpnja 2021.

- N1 Hrvatska (2019b). Kotarac: Od osnutka Fonda se ne radi po zakonima, svi su sve znali. N1info.com. Dostupno na: http:// hr.n1info.com/Vijesti/a446303/Kotarac-Od-osnutka-Fonda-se-ne-radi-po-zakonima-svi-su-sve-znali.html, 10. srpnja 2021.

- N1 Hrvatska. (2019c). Dubravko Ponoš o neradnicima u Fondu za zaštitu okoliša i energetsku učinkovitost. YouTube kanal N1 Hrvatska. Dostupno na: https://www.youtube.com/watch?v=TVfKHI3bc0g, 10. srpnja 2021.

- Osmanagić Bedenik, N. (2010). Krizni menadžment: Teorija i praksa. Zbornik Ekonomskog fakulteta u Zagrebu, 8 (1), $101-118$.

- Plenković, M. (2015.) Krizno komuniciranje. Media, culture and public relations, 6 (2), 113-118.

- Prokić, S., Ranković, Lj., Stefanović, I. (2011). Poboljšanje efektivnosti kriznog menadžmenta kroz primenu savremenih koncepata krizne komunikacije. Singidunum revija, 8 (2), 157-162.

- Smith, R. D. (2016). 25 Strategies for Crisis Communication. Ron Smith. www.ron-smith.com. https://www.ron-smith.com/25strategies-for-crisis-communication, 10. srpnja 2021.

- Šelimber, V. (2019). Uvod. U: Pavlek, M. (ur.), Komunikacija od A do uprava - priručnikza komuniciranje u javnom i neprofitnom sektoru (str. 1-7). Hrvatska udruga za odnose s javnošću.

- Šelimber, V., Jalušić, M. (2019). Odnosi s medijima. U: Pavlek, M. (ur.), Komunikacija od A do uprava - priručnikza komuniciranje u javnom i neprofitnom sektoru (str. 20-27). Hrvatska udruga za odnose s javnošću.

- Tafra-Vlahović, M. (2013). Komunikacijski menadžment: Strategija, modeli, planiranje. Visoka škola za poslovanje i upravljanje s pravom javnosti „Baltazar Adam Krčelić“.

- Tench, R., Yeomans, L. (2009). Otkrivanje odnosa s javnošću. Print.

- Tkalac Verčič, A. (2015). Odnosi s javnošću. Hrvatska udruga za odnose s javnošću

- Tomić, Z. (2008). Odnosi s javnošću: Teorija i praksa. Synopsis.

- Tomić, Z. (2016). Odnosi s javnošću: Teorija i praksa. Synopsis.

- V.B./Hina (2020). AZTN: Prodaja dnevnih i tjednih novina nastavlja padati. Tportal. Dostupno na: https://www.tportal.hr/ vijesti/clanak/aztn-prodaja-dnevnih-i-tjednih-novina-nastavlja-padati-20200617, 10. srpnja 2021.

- Verčič, D. (2016). Why invest in strategic communication? Because it creates value. Communication Management Review, 1 (1), $28-40$.

- Verčič, D., Zavrl, F., Rijavec, P., Tkalac Verčič, A., Laco, K. (2004). Odnosi s medijima. Masmedia. 


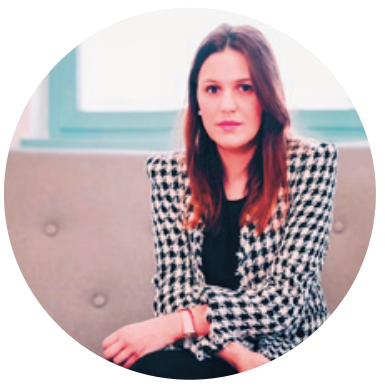

Ivana Jeleč

Ivana Jeleč diplomirala je novinarstvo na Fakultetu političkih znanosti te španjolski i talijanski jezik i književnost na Filozofskom fakultetu. Bavi se strateškom i korporativnom komunikacijom, brendiranjem i reputacijskim menadžmentom, a to su ujedno i teme koje proučava i sa znanstvenog aspekta. Sudjeluje na znanstvenim i stručnim konferencijama, istražuje i piše znanstvene radove, a bila je i dio uredništva hrvatskog prijevoda biografije Edwarda Bernaysa, utemeljitelja struke odnosa $s$ javnošću. Zaposlena je u agenciji za komunikacijski menadžment i savjetovanje Media Val i angažirana je kao predavač na Fakultetu hrvatskih studija i Visokom učilištu Algebra. Doktorandica je na Filozofskom fakultetu Sveučilišta u Zagrebu na studiju informacijskih i komunikacijskih znanosti. Govori tri strana jezika - engleski, talijanski i španjolski jezik. Članica je Hrvatske udruge za odnose s javnošću.

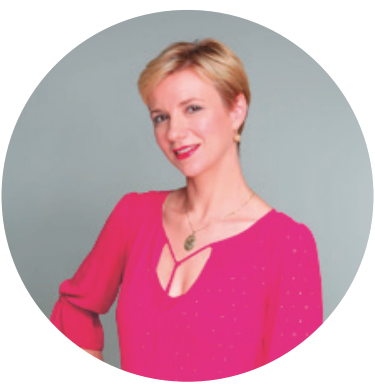

\section{Renata Potočnik}

Renata Potočnik rođena je $\mathrm{u}$ Zagrebu, diplomirala je kroatistiku na Filozofskom fakultetu u Rijeci te je stekla zvanje profesorice hrvatskoga jezika i književnosti, a potom je završila i diplomski studij odnosa s javnošću na Edward Bernays University Collegeu. Paralelno s upisom na Filozofski fakultet počela je raditi u novinarstvu, gdje se zadržala gotovo 17 godina, nakon čega je novinarsku struku zamijenila odnosima $\mathrm{s}$ javnošću te se danas bavi odnosima $\mathrm{s}$ javnošću, s naglaskom na segment odnosa s medijima, kao i strateškom i korporativnom komunikacijom, a sudjelovala je i u brojnim projektima brendiranja. Danas je savjetnica Uprave u Millenium promociji, vodećoj agenciji za integrirano tržišno komuniciranje u Hrvatskoj, i doktorandica na studiju Komunikologije na Sveučilištu u Osijeku.

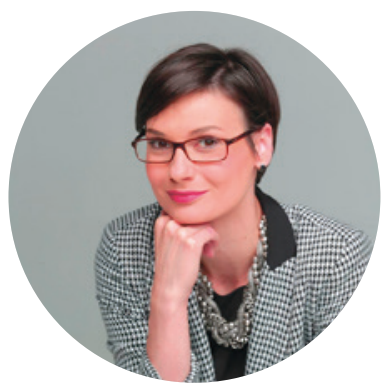

\section{Maja Samardžić}

Maja Samardžić je dugogodišnji predavač na Edward Bernays University Collegeu. Specijalizirana je za područje online medija i digitalnog marketinga. Svoje iskustvo stjecala je u Millenium promociji, agenciji za integrirano tržišno komuniciranje gdje je sudjelovala $u$ planiranju i provedbi mnogobrojnih projekata s područja marketinga i komunikacija. 